\title{
Harnessing pastoralists' indigenous knowledge for rangeland management: three African case studies
}

\author{
Gufu Oba
}

\author{
Correspondence: gufu.oba@umb. \\ no \\ Noragric, Department of \\ International Environment and \\ Development Studies, Norwegian \\ University of Life Sciences, P.O. Box \\ 500, N-1432 Ås, Norway
}

\begin{abstract}
This article reports a rapid method for rangeland assessments in Kenya, Ethiopia and Uganda by harnessing pastoralists' indigenous knowledge among the Orma, Afar and Karamojong pastoralists. The study developed and evaluated a methodological framework for conducting joint assessments with pastoralist range scouts. The framework has four components: selection of ecological and anthropogenic indicators, indicator integration, evaluation of indicator outcomes and regional decision-making systems. The feedbacks between different components were used for information transfer. The framework was applied to the three case studies (using participatory methods). The scouts conducted rangeland assessments using ecological and anthropogenic indicators. Soils, and then vegetation, and finally livestock production were used as the main indicators for understanding rangeland degradation. In addition, pastoralists used key-plant species to assess landscapegrazing suitability and soils to assess landscape-grazing potential. The latter is critical for evaluating potential stocking densities that each landscape could support during the wet or dry grazing seasons. For anthropogenic indicators herders used milk yield, body hair condition, weight gain and mating frequency to assess livestock production performances. Pastoralist scouts assessed rangeland degradation and trends using historical knowledge of the landscapes. The findings confirmed comparable knowledge systems among the three pastoral communities. The methods can be applied across regions where pastoralism still dominates the rural economy. The system of indigenous rangeland assessments and monitoring could rapidly provide information needed by policy makers. Harnessing pastoralists' indigenous rangeland knowledge has implications for participatory research, for verifying and testing methods, as well as for sharing information in order to promote practical rangeland management.

'A camel is a better judge of soils than a herder' (an Afar elder).
\end{abstract}

Keywords: anthropogenic indicators, ecological indicators, indigenous knowledge, landscape grazing potential, rangeland management

\section{包 Springer}

@ 2012 Oba; licensee Springer. This is an Open Access article distributed under the terms of the Creative Commons Attribution License (http://creativecommons.org/licenses/by/2.0), which permits unrestricted use, distribution, and reproduction in any medium, provided the original work is properly cited. 


\section{Introduction}

Pastoral communities' participation in decision making for environmental monitoring is regarded as one of the pillars of sound rangeland management. There are three assumptions involved. Firstly, it is acknowledged that pastoralists have their own experiences and knowledge, which they have used for generations to manage the rangelands. Secondly, it is assumed that their knowledge is measurable and comparable across communities. Thirdly, it is assumed that their knowledge and its outcomes can make an important contribution to the development of local policies. Nevertheless, rangeland researchers have generally not incorporated into their research how this knowledge is generated and may be applied. Its usefulness in complementing existing scientific knowledge for the assessment and monitoring of rangelands is therefore little understood. Indeed, there is limited information on the comparability of indigenous knowledge across pastoral communities in different regions of Africa (see also, Oba et al. 2008a,b; Roba and Oba 2008, 2009). The challenge is to develop standardized methods (Reed and Dougill 2002) using appropriate frameworks for comparative regional studies.

This article selects case studies in East Africa and the Horn of Africa for a regional study on harnessing the indigenous rangeland management knowledge of herders for environmental monitoring. The regions have large pastoralist populations of different ethnicities and cultural groups, who manage camels, cattle and small ruminants. Researchers and policy makers recognise that these regions are experiencing intensification of land use and conflicts, all of which influenced changes in indigenous rangeland management (Gufu Oba forthcoming).

The case studies were concerned with three important questions. Firstly, does the indigenous range management knowledge of pastoralists in East Africa and the Horn of Africa (as developed by multi-ethnic pastoral communities) exhibit common themes in their use of range assessments and monitoring? Secondly, can these indigenous knowledge systems be used for rapid assessments of the communal rangelands in which pastoralists and rangeland ecologists are partners? Thirdly, can a methodological framework be developed for implemention across the region, and would this lead to a common outcome in terms of how pastoralists' knowledge can be used in rangeland assessments and for making rational decisions?

This article comprises six sections. The first section briefly describes herder indigenous knowledge. The second section describes indicator types, while the third section presents a framework for integrating indicator types for rangeland management decision-making. The fourth section introduces the case studies. The fifth section describes step-by-step methods for participatory field surveys for implementing the framework. In the sixth section and sub-sections, the results of the individual case studies are discussed.

\section{The indigenous knowledge and its uses}

The indigenous system of range management has complex features reflecting the interrelationships between human adaptation, environmental variability, systems of land use and local decision-making systems (Little 2003). Indigenous rangeland management knowledge (as used by herders) is the product of environmental management over time (Fernandez-Gimenez 2000; Ford and Martinez 2000; Griffin 2002). Environmental 
condition, livestock production and the social milieu influence herder knowledge (Boardman et al. 2003). The main reason for continuous functioning of indigenous knowledge is that herders put the knowledge to continuous use (Grice and Hodgkinson 2002). In the words of a Somali elder 'a rangeland cannot be a rangeland without pastoralists [knowledge] and a pastoralist cannot [practice pastoralism]...without rangeland' (Bouh and Mammo 2008, p. 115) the two are mutually interrelated.

Herders' indigenous knowledge has potential for promoting local participation in the implementation of the global environmental conventions such as the UN Convention on Combating Desertification and Convention on Biological Diversity (Oba et al. 2008a). This would demand that range scientists become more familiar with indigenous knowledge; its concepts and functions (Mapinduzi et al. 2003) and how the decision-making systems are used for promoting community participation (this study).

This may be appreciated considering that herders have evolved in-depth knowledge in terms of systems of landscape classification, using diverse environmental features such as topography, soil and the dominant vegetation. This is the knowledge that herders use to determine the spatial distribution of livestock grazing (Scharieka 2001). The landscapes have identities. The names describe the physical topography, soils and vegetation. Other names describe historical events. The landscape classification criteria may combine cultural events, such as historical settlements and the types of topography. Grazing landscapes used by herders include key resources grazed during the dry season or drought periods (Illius and O'Connor 2000; Angassa and Oba 2007). The key resources might include marshes, mountain grazing lands, river valleys and floodplains. Policies for alternative economic developments such as irrigated agriculture alienated the rights of herders' access to key resources by disrupting their flexible land use (Kassahun et al. 2008). Under the changed land uses, indigenous knowledge has a powerful explanatory capacity to understand how the altered land use patterns induced land degradation. The practical utility of indigenous rangeland management knowledge for assessing impacts of traditional range management on the environmental requires knowledge of indicator types, which are crucial for decision-making by pastoralists and policy-makers.

\section{Indicator types}

Herders generally use two types of indicators. These are diagnostic ecological indicators and anthropogenic indicators (Brouwer and Crabtree 1999; Dale and Beyeler 2001). The diagnostic ecological indicators reflect relationships between biophysical landscapes and livestock productivity. Plant indicators reflect utility preferences, suggesting that some landscapes (because of their poorer grazing potential) will always be able to support less livestock than others, even under the most favourable weather conditions and management. By linking livestock productivity performance to indicator changes, herders are acutely aware of the production indicators that influence their decision-making on herd movements. The main reason for this is that herders often combine ecological and anthropogenic indicators in rangeland assessments (Oba et al. 2008a). The anthropogenic indicators are part of human environmental history (NAS 2000), products of people's perceptions of local environments (Dale and Beyeler 2001). The types of indicators provide information about the productivity of livestock in terms of milk yield, body condition, and mating frequencies, as well as changes in 
body weight. Adverse changes in both ecological and anthropogenic indicators would imply declining rangeland and livestock productivity. The inferences are at two levels. Firstly, herders take their cue from the condition of the forage by focusing on key forage plant species. Secondly, the herders, by making deductions from livestock production performance, make decisions about changing grazing conditions. These assessments are done simultaneously with those of livestock production performance. Thus, herders gauge knowledge of land degradation in terms of production performances of livestock, and these are invariably related to the status of the soils and key forage plant species. However, unlike ecologists who make general deductions of land degradation, herders perceive that rangeland degradation is relative to the particular species of livestock. These types of indicators reflect landscape-grazing potential (LGP), sensitivity to grazing pressure and the utility values for livestock. How this knowledge works can be explained using a framework.

\section{The framework}

Figure 1 presents the four components of an indigenous knowledge system used in this study. The knowledge comprises indicator selections (i.e. ecological and anthropogenic indicators), indicator integration, evaluation of indicator performances (i.e. for understanding impacts of management) and decision-making systems (i.e. for making policies). The integration of indicators is relevant for organizing comparative knowledge across different pastoral communities. At the local community level, the range science (i.e. ecological knowledge) on one side and herder knowledge on the other (i.e. anthropogenic knowledge), are applied, each providing guidelines for discussing indigenous rangeland management. The integration would focus on indicator selection, assessments and feedback from indicator outcomes. At the local, regional and global levels, harnessing pastoralists' indigenous knowledge can meet the need for improving policies.

The article applies this framework to the following outcomes. Firstly, evaluating how the framework functions across multiple pastoral communities to understand if this would lead to a common outcome in terms of how pastoralists' assess rangelands and

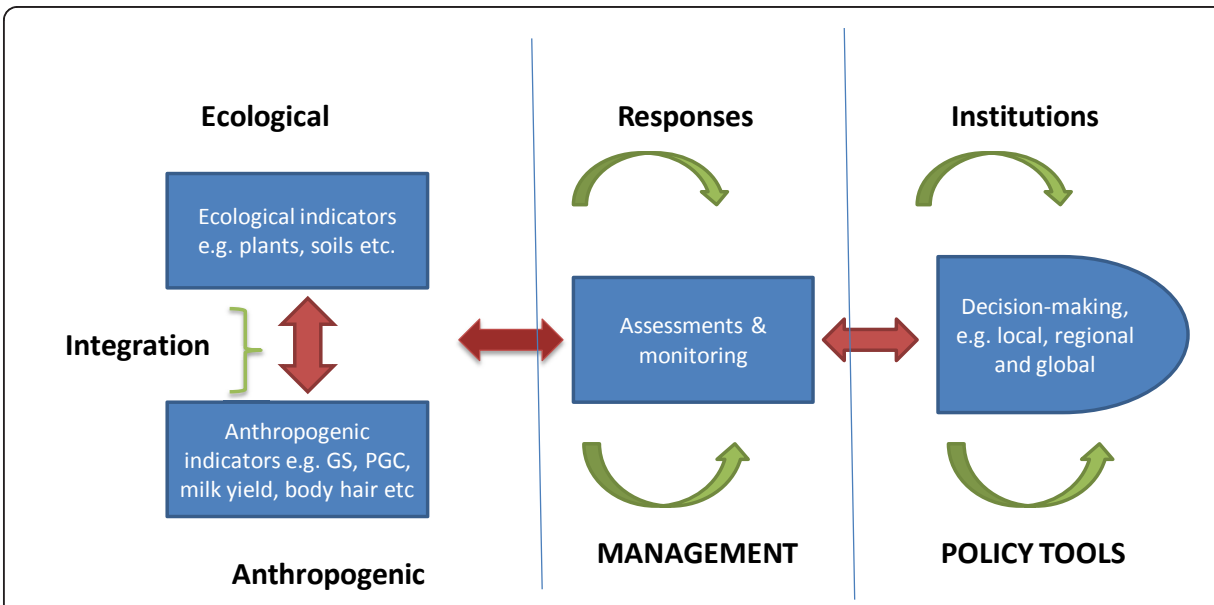

Figure 1 Framework for harnessing herder knowledge for an integrated application of indicators, management decisions in response to assessments and monitoring and policy tools for decision making 
make decisions. The feedback is a means for information transfers between pastoralists, range ecologists and policy-makers (in this study, this last component was not tested in the field). Secondly, understanding if indigenous knowledge can provide rapid assessments of communal rangelands, in which pastoralists and ecologists work in research collaboration. Thirdly, investigating how indigenous range management knowledge exhibits common themes in rangeland assessments and monitoring.

\section{The country case studies}

The surveys were conducted among three pastoralist communities, comprising the Orma (Kenya), the Afar (Ethiopia) and Karamojong (Uganda) from June and July, 2009. In Kenya, the Orma in Tana River District historically occupied one of the richest rangelands in East Africa (Figure 2). The rangelands are semi-arid and highly heterogeneous. Presently, these rangelands are zones of intensive conflict with immigrant pastoralists from neighbouring districts. While land use by the Orma remains pastoral, the district has also attracted large-scale development of irrigated agriculture (Ensminger and Rutten 1991), such as the Bura and Hola irrigation schemes and other planned large-scale schemes in the Tana River delta region that grow sugar cane for bio-fuel. These schemes are currently a source of conflict between the Orma, who feel threatened by displacement, and the Kenyan government, which plans to expand agricultural investment.

Cattle dominate the Orma economy. The key grazing landscapes in the district are the floodplains of the Tana River and other seasonal laaga (dry streams) that serve as fallback during periods of stress. Clearly, the most important grazing resource in the District is the Tana River delta (chaaffa). In the drier areas, there are wells and surface dams (natural and man-made) that create a mosaic of overlapping grazing neighbourhoods around which systems of land use which require livestock mobility have been organied. The Orma rangelands are heavily overgrazed. The greatest threat is from encroachment by Prosopis juliflora, apparently introduced through forestation in the irrigation schemes (Figure 3). This species presently covers $20-30 \%$ of the rangelands in the lower Tana, where it prevents grass growth under canopy (as shown in this study).

The second case study group are the Afar (the group and the administrative district have the same name). The Afar pastoralists territorially inhabit Region 4 of the Federal Republic of Ethiopia (Figure 2). They constitute one of that country's largest pastoralist populations, accounting for about $29 \%$ of the total pastoralist population (Fassil et al. 2001). Ecologically, this region is arid to very arid and is therefore one of the harshest environments in the Horn of Africa. Camels dominate the Afar pastoral production; small ruminants (sheep and goats) and cattle are also important sources of livelihood, but are culturally not as important as camels (Rettberg 2010).

Conflicts with the Isse Somali have adversely affected the Afar indigenous systems of rangeland management and prevented these groups from sharing traditional wet-season grazing lands (Unruh 2005). The insecure rangelands are under-utilised, while the secure areas are over-utilised. The establishment of the Awash National Park and commercial agricultural irrigation in the Awash River floodplain has also removed much of the land required for dry-season grazing by the clans, posing a serious blow to Afar pastoralism. These externally driven changes have altered clan-grazing territories 


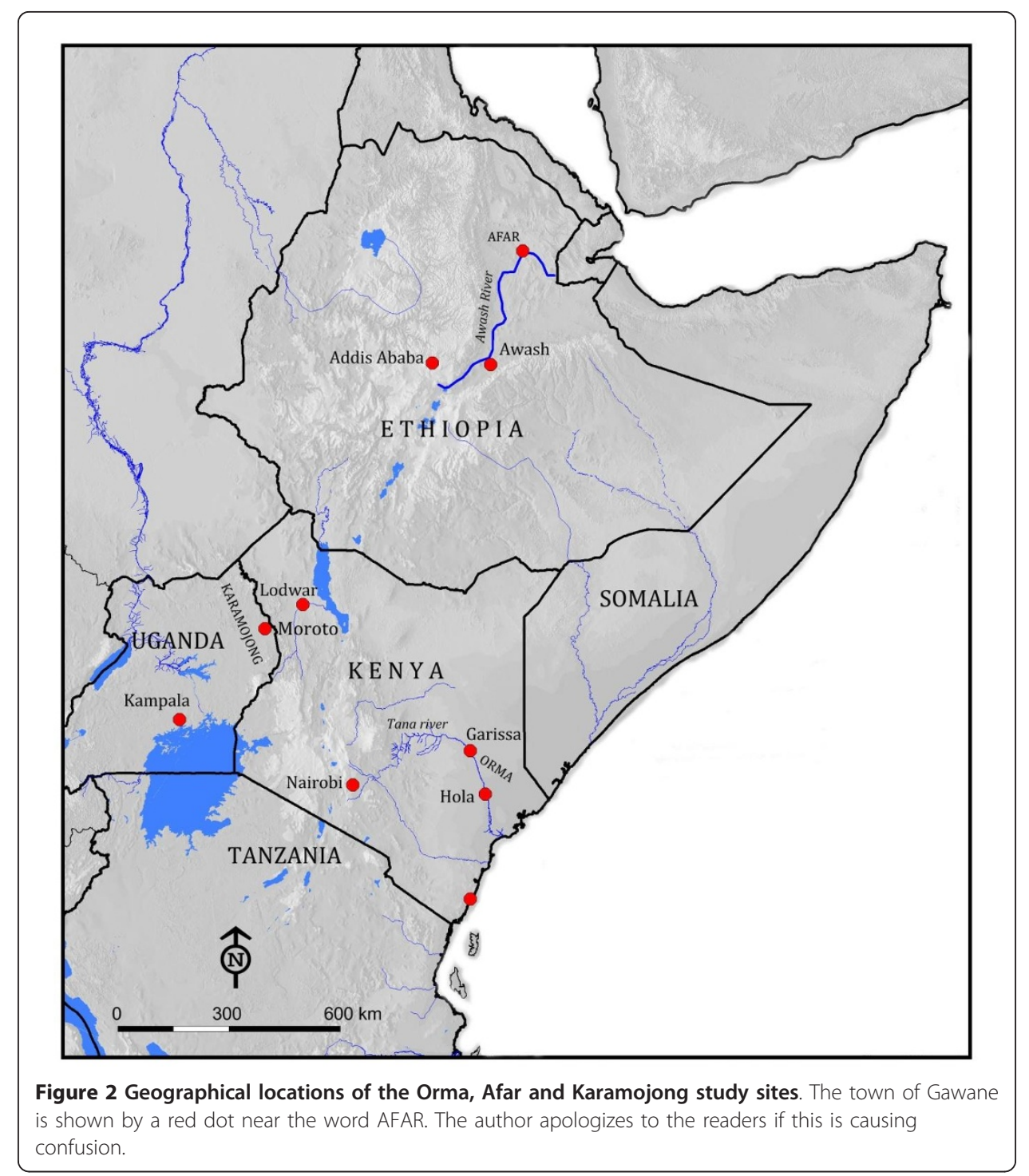

(Getachew 2001). The Afar rangelands in the districts of Amibara and Gawane (considered in this study) are also under threat from the expanding P. juliflora.

The third group are the Matheniko who are members of the Karamojong cluster in Uganda (Figure 2). The Karamojong rangelands are highly heterogeneous and receive the highest rainfall ( $>450 \mathrm{~mm}$ per year) compared to the Orma and the Afar rangeland areas. As a result, these rangelands contain rich pasturelands, and transhumance movements take place between the lowlands in the wet season and the marshes and mountains in the dry season. The Matheniko occupy the rangelands around the town of Moroto. Their grazing lands extend to the western borders of Kenya, occupied by the Turkana pastoralists, with whom the Matheniko share resource use networks, as well as occasional conflicts. The Matheniko have a tradition of cultivating home gardens (nikiror). Their settlements are semi-permanent: with some settlements having remained in the same place for several generations. ${ }^{a}$ Cattle raiding was an endemic problem in Karamoja region and following government intervention, the Karamojong were disarmed of their AK 47 automatic rifles and placed in security settlements 


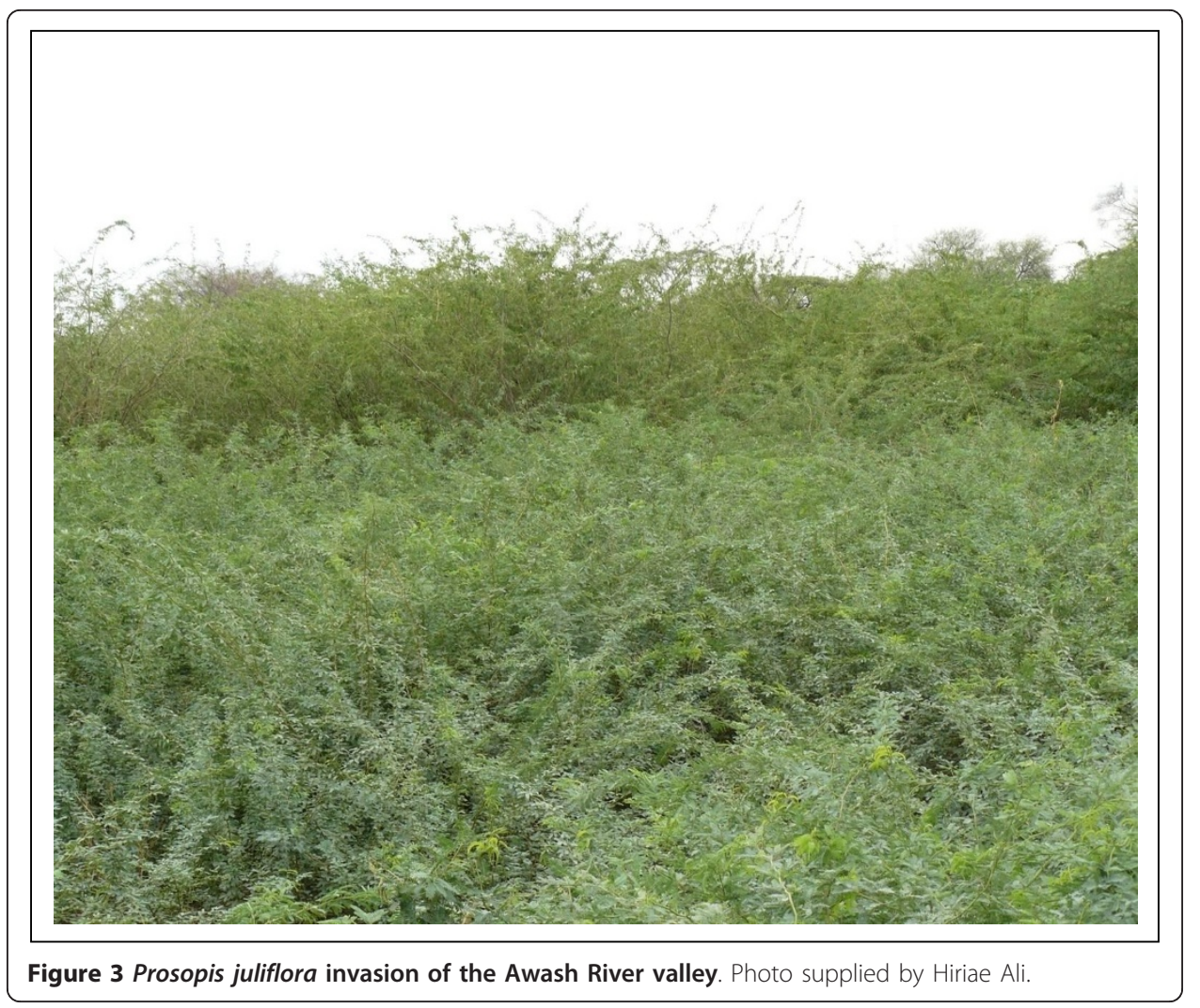

guarded by the military personnel; this had serious economic consequences (Agade 2010; Stites and Akabwai 2010; Knighton 2010).

\section{Survey methods}

The methods for implementing the framework consisted of seven systematic steps which were repeated in all the three areas (Table 1). In Steps 1-3, the goal was to gain an overview of indigenous rangeland management methods used by the selected communities. Key informants-often knowledgeable elders selected by their communitieswere interviewed to provide general information about the geographical and ecological make-up of the grazing lands. The interviewees described ecological zones, herder systems of landscape classification and resource allocations between different grazing seasons (see also Oba and Kaitira 2006; Roba and Oba 2008). Composite lists of terms, concepts and indicators used by the herders in each community were compiled. The discussions with key elders also considered indicator functions in relation to livestock production (Oba et al. 2008a).

In Steps 4-6, the survey team used a vehicle odometer to mark sampling intervals with rural roads serving as transects. The surveys were set at 5 or $10 \mathrm{~km}$ intervals, depending on the distances covered (with longer distances using the longer intervals and vice versa). These were done in order to sample as many landscapes as possible. This sampling frame approximates the scale of surveys traditionally conducted by pastoralists to cover large areas. Sampling was at about $200 \mathrm{~m}$ from the roads in the selected landscapes to avoid 'road effects'. At this distance, the herder range scouts conducted traditional assessments at landscape patch scales. The herder scouts 
Table 1 The steps needed to implement the framework (Figure 1) by describing the ecological and anthropogenic indicators ${ }^{a}$

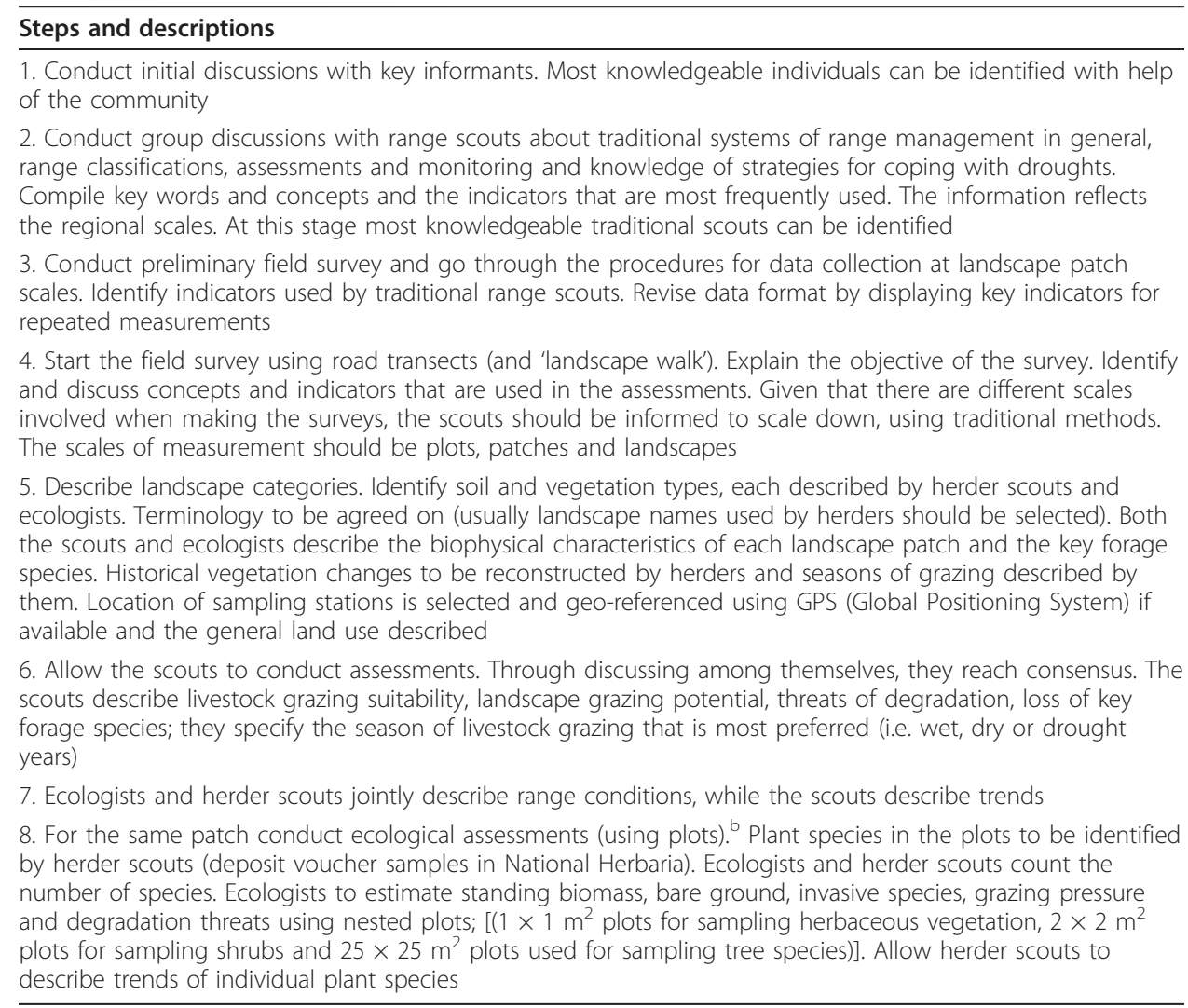

Note. Step 8, which involves ecological measurements were not implemented in this study.

${ }^{a}$ Modified from Oba et al. (2008a, p. 71).

${ }^{\mathrm{b}}$ For the present study only steps 1-7 were implemented due to time constraints.

identified individual landscapes using their geographical, historical and ecological identities (see below). Using anthropogenic indicators, they then rated the grazing suitability (GS) for different livestock species and assessed LGP during the different seasons of grazing. At the same time, they took into account other value-laden indicators related to LGP. The GS is plant-based and therefore reflects high spatial variability, while the LGP is based on the physical environment, such as soils, and is a more stable indicator. The LGP is a relative measure of the resilience of landscapes. Landscapes with low potential are vulnerable to heavy grazing pressure (Oba et al. 2008a). This is inferred from the soils, which erode easily. The landscapes with low potential had more annual grasses than perennial grasses. One should remember that GS and LGP are assessed on ordinal scales (which in this case were coded by the ecologist as low $=1$, medium $=2$ and high $=3$ ).

The herder scouts also assessed the current grazing pressure (using the scale: none, low, moderate, heavy and very heavy). The scales were dependent on multiple indicators. These included levels of plant utilisation (none, moderate, heavy or very heavy); density of hoof tracks (none, moderate or numerous); density of faecal deposits (low, moderate or high); and density of present and previous human settlements (none, moderate or dense). The herders described the degradation vulnerability of each landscape in terms of vegetation and surface soil movements. These were rated as low, 
moderate, high or absent. In describing threats to key forage species, the herder scouts described the landscapes most at risk. For each landscape surveyed, herder scouts were asked to describe trends of vegetation change (Oba et al. 2008a,b). These are based on their historical knowledge (e.g. from when they were young herders compared to the present). It was however, the decline or the loss of the key forage species, which described the trends.

In Steps 7-8, the survey integrated the ecological and anthropogenic indicators. Using their own language, the herders rated range conditions as highly 'desirable', 'moderately desirable', 'desirable' or 'undesirable' in relation to each landscape patch that was surveyed. Thus, landscapes with little or no evidence of invasive species, with high grass cover, and where all key forage species were present, received 'highly desirable' condition ratings-in contrast to landscape patches where invasive species have replaced key forage species, or which were severely degraded. The herder scouts used their historical knowledge to describe trends (i.e. increasing, decreasing or stable). Changes in grazing suitability varied with different livestock species. Suitability for livestock grazing and camping was described in terms of soils. Herders' historical knowledge of landscape suitability is transmitted through folklores that informs about the interactions between their livestock and the environment. The songs were passed on from one generation of herders to the next. In order to capture the indigenous knowledge of each community, their assessments were presented as cases.

\section{Results and discussions}

The findings of the surveys in the three areas are summarized in Tables 2, 3 and 4 . The indigenous rangeland management systems incorporated societal knowledge of the classification of indigenous rangelands-their landscape categories, grazing neighbourhoods, key and non-key resources, access to the wet-and the dry-season grazing landscapes, and, most importantly, how the dominant livestock species influenced the types of rangeland management.

Folklore was an essential element of information transfer regarding indigenous range management in all three communities. The indigenous rangeland assessments used knowledge of soils, vegetation, livestock grazing preferences and the suitability of different landscapes to regulate wet- or the dry-season grazing movements. The herders' rationale for the classification of landscape was to determine its potential for livestock grazing. This was important as a guide to the regulation of stocking densities across landscapes. This factor, which has not adequately been acknowledged by rangeland ecologists, is critical for understanding the functions of the indigenous knowledge of rangeland management and therefore as an indication of what we might achieve by harnessing pastoralists' indigenous knowledge. We begin with the findings from the Orma case study, first in general and then focusing on the results presented in Table 2.

\section{Case 1: the Orma of Kenya}

The indigenous knowledge of the Orma is built around cattle management. Their systems of grazing at the broader scales combined key grazing resources, which were divided into grazing social networks (mata dedha). ${ }^{\mathrm{b}}$ Each mata dedha formed a mosaic of grazing landscapes of different quality, allowing the Orma to establish access through mutual grazing social networks. Within individual grazing associations, grazing 
Table 2 Herder scouts and ecologist's assessments of the Orma rangelands at landscape scale

\begin{tabular}{|c|c|c|c|c|c|c|c|c|c|}
\hline $\begin{array}{l}\text { Transect } \\
\text { name }\end{array}$ & $\begin{array}{l}\text { Landscape } \\
\text { classification }^{\mathrm{a}}\end{array}$ & $\begin{array}{l}\text { Soil } \\
\text { indicator }^{b}\end{array}$ & $\begin{array}{l}\text { Season of } \\
\text { grazing }\end{array}$ & $\begin{array}{l}\text { 'Grazing suitability' } \\
\text { (GS) }\end{array}$ & $\begin{array}{l}\text { d Landscape grazing } \\
\text { potential }^{2} \text { (LGP) }\end{array}$ & Condition $^{e}$ & Trends $^{f}$ WC & $\mathrm{GP}^{\mathrm{g}}$ & Degradation $^{\mathrm{h}}$ \\
\hline \multirow[t]{2}{*}{$\begin{array}{l}\text { Moye Buya } \\
\text { Guyo }\end{array}$} & Wayaama & Red soil & Wet & Goats-High & Low-cattle & Moderate & $25 \%$-Stable & $\mathrm{VH}^{\mathrm{i}}$ & $\begin{array}{l}\text { Threat high But } \\
\text { resilient }\end{array}$ \\
\hline & & & & Cattle-low & & & & & \\
\hline \multirow[t]{3}{*}{ Qote Jijiga } & Omaara salaj & Gray & Dry & Cattle-high & High-cattle & Good & $50 \%$ & $\mathrm{VH}$ & $\begin{array}{l}\text { Threat high but } \\
\text { resilient }\end{array}$ \\
\hline & & & & Goats-low & & Fair & Declining & $\begin{array}{l}\text { Bare ground } \\
-80 \%\end{array}$ & \\
\hline & & & & $\begin{array}{l}\text { Reduced by bush } \\
\text { encroachment }\end{array}$ & & & & & \\
\hline \multirow[t]{2}{*}{ Onmirti } & Omaara-adhik & White & Wet/dry & Cattle-high & High-cattle & Poor & $\begin{array}{l}\text { Declining, invasive sp. } \\
\text { WC } 30 \%\end{array}$ & $\mathrm{VH}$ & Threat high \\
\hline & & & & & & & & $\begin{array}{l}\text { Bare ground } \\
60 \%\end{array}$ & But high resilient \\
\hline \multirow[t]{2}{*}{ Komora Jiila } & Omaara-adhi & White & Wet/Dry & Cattle-high & High-cattle & Moderate & Stable & $\mathrm{H}$ & Threat moderate \\
\hline & & & & Goats-moderate & & & WC no change & $\begin{array}{l}\text { Bare ground } \\
30 \%\end{array}$ & \\
\hline Bura-Komora & Biiy-boora & Dark soil & Wet & Only camels & Low & Poor & Declining, WC 50\% & Bare $80 \%$ & Threat high \\
\hline
\end{tabular}

aClassified by the abuuru scouts.

${ }^{\mathrm{b} C l a s s i f i e d ~ b y ~ t h e ~ a b u u r u ~ s c o u t s . ~}$

'Rated by the abuuru scouts.

dibid.

e Jointly rated by ecologist and the abuuru scouts on the survey team.

${ }^{f}$ Rated by the abuuru scouts and woody cover estimated by ecologist.

${ }^{9}$ Grazing pressure (GP) assessed by the abuuru scouts.

hoint rating by abuuru scouts and ecologist.

'Very high (VH).

JThe oomaar soil of the Oryx (saala).

${ }^{k}$ White oomaar landscape with gray soils showing the presence of limestone

GS, grazing suitability; LGP, landscape grazing potential; WC, woody cover; GP, grazing pressure; VH, very high; $\mathrm{H}$, high. The indigenous words are explained in the text. 
Table 3 Herder scouts and ecologist's assessments of the Afar rangelands at landscape scale

\begin{tabular}{|c|c|c|c|c|c|c|c|c|c|}
\hline $\begin{array}{l}\text { Transect } \\
\text { name }\end{array}$ & $\begin{array}{l}\text { Landscape } \\
\text { classification }^{a}\end{array}$ & $\begin{array}{l}\text { Soil } \\
\text { indicator }^{b}\end{array}$ & $\begin{array}{l}\text { Season of } \\
\text { grazing }\end{array}$ & $\begin{array}{l}\text { cGrazing } \\
\text { suitability }{ }^{3} \text { (GS) }\end{array}$ & $\begin{array}{l}\text { d Landscape grazing } \\
\text { potential }^{4} \text { (LGP) }\end{array}$ & Condition $^{\mathrm{e}}$ & Trends $^{f}$ WC & $\mathrm{GP}^{\mathrm{g}}$ & Degradation $^{\mathrm{h}}$ \\
\hline \multirow[t]{3}{*}{$\begin{array}{l}\text { Diktaa } \\
\text { Boora }\end{array}$} & Raasa & Black & Dry & Camels-high & High for all species & Fair & Stable & Heavy & $\begin{array}{l}\text { Kaffiin isoole baaro' But } \\
\text { resilient }\end{array}$ \\
\hline & & & & Goats-high & & & $W C<20 \%$ & & \\
\hline & & & & Cattle-High & & & & & \\
\hline \multirow[t]{2}{*}{ Dadaamo } & Koma & Rocky & Wet & Goats-moderate & Moderate-goats & Poor & $\begin{array}{l}\text { Downward invasive sp. } \\
\text { expanding }\end{array}$ & Heavy & Aboroiti baaro \\
\hline & & & & Camels-low & & & WC > 40\% & & $\begin{array}{l}\text { This land would require } \\
\text { heavy investment }\end{array}$ \\
\hline \multirow[t]{2}{*}{ Adoptili } & Hududo & White & Wet & Low for all species & High & Very poor & Downward & $\begin{array}{l}\text { Zero } \\
\text { herbaceous } \\
\text { cover }\end{array}$ & Aboroiti baaro \\
\hline & & & & & & & WC $70 \%$ Prosopis & & Requires heavy investment \\
\hline \multirow[t]{2}{*}{ Intiasso } & Daale-Raasa & $\begin{array}{l}\text { Black with } \\
\text { pebbles }\end{array}$ & Wet & Camels-low & High & Poor & Downward & Very heavy & Aboroiti barro \\
\hline & & & & Goats-low & & & Invasive sp. & & Requires heavy investment \\
\hline $\begin{array}{l}\text { Hunda } \\
\text { halaidi }\end{array}$ & Dalle-Raasa & $\begin{array}{l}\text { Black with } \\
\text { pebbles }\end{array}$ & Wet/dry & High for all sp. & High & Excellent & Stable & Light & Andarhaarra $^{k}$ \\
\hline
\end{tabular}

${ }^{a}$ Classified by the iddo scouts.

${ }^{\mathrm{b}}$ Classified by an ecologist and by iddo scouts.

'Rated by the iddo scouts.

${ }^{\mathrm{d}}$ lbid.

e Jointly rated by ecologist and the iddo scouts on the survey team.

${ }^{f}$ Rated by the addi scouts; woody cover estimated by an ecologist.

${ }^{9}$ Grazing pressure (GP).

hoint rating by iddo scouts and an ecologist.

'Slight; the landscape has dry grass cover of $20-30 \%$.

'Degraded of herbaceous layer.

${ }^{k}$ Excellent condition; the area is a buffer zone between two conflicting groups.

GS, grazing suitability; LGP, landscape grazing potential; WC, woody cover; GP, grazing pressure; VH, very high; $\mathrm{H}$, high. The indigenous words are explained in the text. 
Table 4 Herder scouts and ecologist's assessments of the Matheniko rangelands at landscape scale

\begin{tabular}{|c|c|c|c|c|c|c|c|c|c|}
\hline $\begin{array}{l}\text { Transect } \\
\text { name }\end{array}$ & $\begin{array}{l}\text { Landscape } \\
\text { classification }^{a}\end{array}$ & Soil indicator ${ }^{\mathrm{b}}$ & $\begin{array}{l}\text { Season of } \\
\text { grazing }\end{array}$ & $\begin{array}{l}{ }^{\mathrm{C}} \text { Grazing suitability }{ }^{5} \\
\text { (GS) }\end{array}$ & $\begin{array}{l}{ }^{\text {d Landscape grazing }} \\
\text { potential }^{6} \text { (LGP) }\end{array}$ & Condition $^{\mathrm{e}}$ & $\begin{array}{l}\text { Trends } s^{f} \\
\text { WC }\end{array}$ & $\mathrm{GP}^{\mathrm{g}}$ & Degradation $^{\mathrm{h}}$ \\
\hline \multirow[t]{2}{*}{$\overline{\text { Moru Kakeroi }^{i}}$} & $\begin{array}{l}\text { Angromit nalokob } \\
\text { emoru' }\end{array}$ & $\begin{array}{l}\text { With Pebbles, soil colour } \\
\text { varied }^{k}\end{array}$ & Dry & Cattle-High & High-cattle & Excellent & Stable & Light & Amoone \\
\hline & & & & & & & WC 30\% & & \\
\hline \multirow[t]{2}{*}{ Nakiloro $^{m}$} & $\begin{array}{l}\text { Angromit } \\
\text { nararuakinit }^{\text {n }}\end{array}$ & Lava stone, dark soil & Wet/dry & Camels-high & High-camels & Fair & Declining & Heavy & Erekeny $^{\circ}$ \\
\hline & & & & Goats-moderate & & & WC $40 \%$ & $H C<20 \%$ & \\
\hline \multirow[t]{2}{*}{ Kautakowu ${ }^{p}$} & Eketela longiro ${ }^{9}$ & White-red & Wet & Cattle-high & High-cattle & Good & Stable & $\begin{array}{l}\text { Light- } \\
\text { Moderate }\end{array}$ & $\begin{array}{l}\text { Amoone } \\
\text { napachol' }\end{array}$ \\
\hline & & & & & & & WC $25 \%$ & $>40 \%$ & \\
\hline Morlinga & Ekowath ${ }^{\mathrm{s}}$ & Mixed & Home garden & Cattle-high & High-cattle & Good & Stable & Moderate & Nginarekeny ${ }^{t}$ \\
\hline Namorungora & Arro & Black & Dry & Cattle-high & High-cattle & Fair & Downward & Heavy & Erekeny \\
\hline
\end{tabular}

${ }^{a}$ Classified by the ngikerebo scouts.

${ }^{\mathrm{b} C l a s s i f i e d ~ b y ~ e c o l o g i s t . ~}$

'Rated by the ngikerebo scouts.

dibid.

e Jointly rated by ecologist and the ngikerebo scouts on the survey team.

'Rated by the ngikerebo scouts; woody cover estimated by ecologist.

${ }^{9}$ Grazing pressure (GP).

hoint rating by ngikerebo scouts and ecologist.

'Mountain of shrine.

'Landscapes with pebbles (angromit) that slopes (nalokob) from mountain (emoru).

${ }^{k}$ Angromit nagor (dark soil with pebbles), Angromit narangan (stony and red).

'High grass cover with little evidence of grazing.

mBushy.

"Lava stones with dark sandy soil.

'Heavily grazed with low grass cover.

PPlateau-like.

${ }^{\mathrm{a}}$ Bushed grassland.

'High grass cover with open spaces.

${ }^{\mathrm{s}}$ Transitional landscape between Arro (black) and eketela (sandy).

tSome level of use between erekeny (heavily used) to amoone (little used). The transition is called Nginarekeny.

GS, grazing suitability; LGP, landscape grazing potential; WC, woody cover; GP, grazing pressure; VH, very high; $\mathrm{H}$, high. The indigenous words are explained in the text. 
landscapes are allocated to either wet, dry or drought grazing. The wet-season grazing landscapes are visited during the rainy season when the rain pools (hoora) are full of water. As soon as these pools are exhausted, the communities return to their traditional dry-season grazing lands (the river floodplain and the delta). One informant emphasised the importance of the delta for pastoral grazing as follows: 'The chaaffa of Tana is not just grazing land for cattle; it is our [means of] survival...'

The Orma informants suggested that their systems of management depended on conservation of the grazing lands (although not in any prescriptive sense) through rotational grazing between seasonal grazing landscapes. They achieved this by regulating grazing movements between different mata dedha associations during different seasons. As soon as the rains return, the grazing of the floodplain ends and the population returns to the wet-season grazing. However, when the dry period is extended and the river pastures are exhausted, the cattle camps move back to the wet-season grazing areas, with the livestock walking to the river for watering. While the indigenous rangeland management system is a social-environmental construct, the livestock is the medium through which the Orma pastoralists express the value placed on grazing lands. The suitability of grazing landscapes forms part of folklore (called darma), which transmits information about the past and present environments. The cattle folklore describes livestock watering, grazing movements and coping with environmental stress. The expression, 'this or that grazing land has darma', implies that the grazing suits a specific species of livestock. An area that fails to catch the attention of the folklorist's darma is regarded as unsuitable for livestock grazing.

\section{Indigenous rangeland assessments}

The Orma have expressions that reflect the potential of the land. Metaphorically, this is described as the 'hump' (dhaallu) and the 'breast or rump' (andaaraaf) of a cow, which are regarded as the high-quality fatty portions of meat. The grazing lands with dhaallu and andaaraaf equivalents are highly valued as key resources. At the landscape scale, the Orma's indigenous knowledge of range management is organised in terms of soil type and vegetation. The Orma prefer white-gray soils (oomaar) compared to other soil types. The oomaar vegetation is claimed to be highly nutritious and the livestock that grazes on it does not lose body condition, even during periods of high stress. Such soils are claimed to have geebiba-an inherent property of suitability that reflects the preference of land use. Conversely, the livestock that grazes on the red wayaama soils do suffer weight loss (see also Oba and Kotile 2001). The characteristic feature of the red soil is its tendency to be dusty, and the Orma regard this as unsuitable for cattle management. The presence of Cordia species (madheera itile qaaya) reflects the geebiba soils of the oomaar landscapes. The herders test the soil by poking the surface with sharp sticks to determine the depth of the gray-white soils. If a layer of red wayaama soil is found near the surface, the camp is moved. The Orma try to avoid mixed soils (of oomaar and wayama) for livestock grazing and for camping. They refer to soils such as oomaar uufte baaru (the spotted oomaar soils).

The sandy ramata landscapes, which tend to form piles of soil due to soil movements, are also avoided when it comes to locating pastoral settlements. Ideally, the Orma herders would utilize the oomaar landscape for dry-season grazing, followed by grazing in the floodplain and the delta landscapes. The black soil (kooticha) is suited to wet-season grazing but unsuitable for use for pastoral settlements. ${ }^{\mathrm{c}}$ The kooticha soils 
are said to be 'cold' during the night and the livestock kraaled in them is said to rapidly lose body condition. After camping for the night, herders would re-examine their preferences in the light of changes in livestock behaviour (Roba and Oba 2009). Landscapes where livestock become restless during the night and their body condition declines rapidly are regarded as unsuitable. In this case, it is the livestock behaviour that serves as the barometer for measuring environmental unsuitability.

The productive and reproductive performance of cattle is closely related to soil conditions. The herders feel that the kooticha (black soil) lacks geebiba. Indicators of this are forage plants that provide roughage but have little nutritional value. The herders use two types of indicators to assess the quality and suitability of forage in the black soil (kooticha). Firstly, the cattle grazed in the kooticha soils develop enlarged rumen, which indicates forage with little nutritional value. Secondly, the herders recognize that cattle grazed in the kooticha landscapes deposit large pats, which are also indicators of poor forage quality. From this evidence, the Orma conclude that livestock grazed in unfavourable soils loses weight more rapidly, while livestock grazed in better quality soils gains weight. The wayaama (red soils) are better suited to small ruminants. This soil type is associated with browse plants (see also Oba et al. 2000; Oba and Kotile 2001).

Decisions on livestock grazing at the landscape level depend on extensive surveying and assessment of rangeland production indicators. The range scouts (abuuru), usually young experienced herders, are sent by the elders to assess rainfall and forage conditions. If the water in the different pools was sufficient, the range scouts would then survey to see if forage conditions would support the livestock for a given period. The Orma recognize three types of pasture conditions resulting from different types of rainfall and livestock grazing. The koono showers that fall in the dry season may be sufficient to promote the growth of browse vegetation but are insufficient to sustain the growth of grass, and therefore would not be a reason for migration to such areas. The second type of pasture is a result of heavy rainfall, which encourages high pasture growth. This is refered to as ooba, describing high biomass. The third type is an overgrazed rangeland (hinbarbadoofte)-avoided as much as possible.

Other series of indicators relate to the body condition of the livestock already present in the surveyed rangelands. The range scouts assess the composition and texture of the cattle pats. The inference is that where cattle drop large pats the grazing landscapes lacks fiina. This undefined property sums up the condition of the livestock. Fiina as an indicator has spatial and temporal variability. In landscapes which lack fiina, even when there is sufficient forage production, for some inexplicable reason livestock might continue to lose condition, thus forcing the herders to move to other areas, where better conditions might exist. Such landscapes would be avoided. The abuuru (range scouts) also closely examine the behaviour of the livestock present. Playful behaviour of cattle, increased activity on the part of the bulls, cattle that 'sleep' (chiisa) at night for long periods and chew the cud, a full rumen and 'polished' body hair are all indicators of favourable conditions (Roba and Oba 2008).

Every landscape that is surveyed has a history of settlement and decisions are based on this experience. The abuuru transfers the information to the elders by geographically locating each surveyed landscape. The elders evaluate the information by asking questions related to water availability, pasture conditions, existing stock numbers, the 
number of settlements and the reproductive performance of cattle already present in the area. Based on this information, the elders may then recommend moving the dry herds (foora) to the surveyed rangelands. We put this knowledge to test by surveying jointly with the abuuru scouts using road transects.

\section{Evaluation of indigenous rangeland assessments by the Orma}

The road survey from the Garissa-Hola road junction to the Hola irrigation scheme covered a total distance of $150 \mathrm{~km}$ (Figure 2). The abuuru scouts described the landscapes. They used different types of names. Personified names reflect historical settlements and the physical contours of the landscape, the dominant tree species and the rituals historically performed at the sites. A place name such as 'Moye Buya Guyo' refers to geographical identity and is also a person's name (Table 2). The word 'Moye' refers to hornless cattle; the name probably refers to a historical settlement where the 'hornless' cattle of Buya Guyo once settled. However, the informants suggested that the name might refer to clay pots (mooye-note the Oromo name for pot is okhoote faara) that were made at the site by the family. Whatever the historical interpretation, there are no other landscapes by that name, making it a geographical space that can be used to direct grazing and settlements. The other location was called Komoora Jiila. This refers to a depression in the landscape (komoora)-which might imply a historical location where cattle herds were kraaled; over time, their hooves may have created the depression. ${ }^{\mathrm{d}}$ This interpretation is probably accurate because of the hint contained in the second name-Jiila-that refers to a ritual ground where the Orma used to conduct the gada ceremonies (see later section). There are other names: Qoote (Cordia species), Jijiga (settlement) and Oonmirti. Here the name is in two parts, Oon and Mirti, referring to an old settlement (Oon) and to a kind of tree species (Mirti) found in the locality. From these landscape names, one can infer that the herders, like cartographers, used place names with historical derivations. However, unlike cartographers, the herders attached meanings to all place names (Turner and Hiernaux 2002).

The same landscapes were classified ecologically by the range ecologist using soils and vegetation as a secondary indicator (see Berlin 1973). Thus, more accurate landscape classifications of the first transect (Table 2) is wayaama-ameesa (the red soil of Commiphora africana). This is a typical woody plant species found in red soils; often forming thickets (compare this with the study earlier conducted in southern Ethiopia by Oba et al. 2000). This type of vegetation is widespread throughout the region. By comparison, the soil type of oomaar, which is highly valued for cattle grazing, occurs in combination with oomaar-adhi, the white soil, which is characteristic of cattle country and supports key perennial grass species. A variant, oomaar saala, is the typical habitat of the oryx, hence, the suffix saala. Therefore, the name oomaar saala indicates to the herders that this particular landscape would not be suitable for human settlement. ${ }^{\mathrm{e}}$ In most of the landscapes surveyed, the main threats to grazing suitability were increased bush cover and heavy grazing pressure. The latter was inferred from the presence of bare soil stripped of herbaceous cover. The grazing suitability was reduced by the presence of $P$. juliflora in all the landscapes. With one exception, the condition of the landscapes had deteriorated, according to the assessments of the abuuru scouts. Range condition was either fair or poor, and the trend was in decline (Table 2). We discussed with the abuuru scouts how the information was used in their decision making. 


\section{The Orma's indigenous institutions for decision-making}

The selection and application of indicators showed that indigenous knowledge influenced the decision-making system through the institution of jaarsa mata dedha (elder councils of grazing associations) which were responsible for governing the grazing neighbourhoods. The institution of jaarsa mata dedha used customary (aada) laws (seera) that functioned under the former gada system that regulated access to grazing and water resources. Most significantly, the ritual site previously used by the gada assemblies $^{\mathrm{f}}$ was the focal point for holding the annual assembly of Jaarsa mata dedha. The Jaarsa mata dedha institution has political, social and decision-making functions. The assembly is a place for discussing conflicts over grazing lands with other pastoral groups. It is also the means by which the Kenyan government communicates policies to the communities. The function of the assembly is to reinforce community-wide decision-making that has wide-ranging application, including the power to decide who may have access to the Orma traditional grazing lands. This institution is therefore important for mobilizing the Orma in combating land degradation. The findings from the Orma case study may be compared with the Afar case, now described. These are treated generally at first and the main results in Table 3 then discussed.

\section{Case 2: the Afar of Ethiopia}

The Afar moved between grazing landscapes that were geographically divided between the uplands (ale), the lowlands (bahari) and between narrow (duulul balaa) and wide valleys (daaba) within the Afar rangelands that stretch between Ethiopia, Eritrea and Djibouti (Figure 2). The floodplain of the Awash River (kaalo) with its key grazing resources served as a dry-season grazing reserve, while the uplands were used for wetseason grazing. The plains were grazed soon after the rains when the soils dried and the grasses flowered. The pattern of grazing movements and the selection of different grazing landscapes varied according to the type of livestock species. On a broader scale, the Afar rangelands comprised communal grazing areas, where all the neighbouring clans shared grazing and water during the wet season. Each clan had a territory (faage) to which their livestock returned during the dry season when the communal grazing had been exhausted (Müller-Mahn et al. 2010).

The Afar's grazing patterns depended on the assessments conducted by the traditional range scouts (iddo). Their system of rangeland assessments took into consideration the requirements of different livestock species. Camels, being browsers, have different needs than those of cattle. The iddo scouts paid particular attention to the availability of browse plants, while in the case of cattle, the scouts would assess the condition of grasses. Their assessments would always focus on the availability of key forage species. Depending on the time of the year, they might also consider the stages of plant growth, from early season to late season growth. The Afar herders recognise that degraded environments are not suitable for livestock grazing. They also take into account access to salt licks and salty plants, particularly for camel management. The grazing requirements vary seasonally. In years of above-average rainfall, their rangelands produce abundant grazing for the different species of livestock. The herders have considerable freedom of choice when selecting grazing areas. For example, camels avoid the muddy soils of the plains and move to the uplands where the ground is firmer underfoot. Small stock also prefers the uplands, as they are better adapted to walk 
on rocky surfaces. Cattle, in contrast, prefer the lowlands and avoid the stony uplands. Thus, camels and the smaller ruminants come down from the uplands and return to the plains only after the soil surface has hardened after the rains.

When planning pastoral encampments, the Afar herders would break up the soil surface (compare this to the Orma's practice) to assess if sand and grits or pebbles are present. Soils that lack these features are considered unsuitable for kraaling livestock. In the surveyed landscapes, pebbles were spread on the surface to form hard ground (inde laala). Other soil types are white soils (adosisa), black soils (raasa) and rocky landscapes (dalle baaro). Camels prefer raasa for grazing. The small stock prefers inde laala, while cattle prefer adosisa baaro (white soil). The black-gray soil (stakala) is preferred for grazing by all livestock species, but is unsuitable for the establishment of pastoral encampments. Soft soil without pebbles (doole baaro) is not suited to the management of small ruminants. The Afar herders claim that if goats graze in the doole baaro landscapes for long periods, their hooves are likely to grow. The herders prefer inde laala (soils with pebbles and a hard surface) to trim their hooves.

The iddo scouts on their return are interviewed by the elders who evaluate their information. Making errors of judgment is risky as this may result in the loss of livestock; for this reason all information is carefully evaluated. The elders consider the evidence presented and weigh up potential risks of moving. If they are not satisfied with the information, they will redeploy the scouts to survey different areas. If they are satisfied with the information, the clan elders will either split the milk and dry herds, or move the whole herd. Their decisions are communicated through the system of daago (i.e. a word of mouth) to neighbouring clans. After the grazing landscapes have been selected, the herders focus on the physical condition of the livestock, on milk yields, and on the activities of the breeding males.

As primarily camel pastoralists, the Afar iddo scouts prioritise the needs of their camels. According to the Afar herders, camel management is a crucial aspect of indigenous rangeland management. Camels require a particular grazing landscape during different seasons of the year. The choice of grazing area is based not only on topographic conditions but also on the dietary requirements of the camels. According to the herders, 'camels [are] selective in their feeding habits', while cattle are less particular when it comes to grazing; small ruminants, on the other hand, do not have as wide a choice. In view of the Afar herders, camels, unlike other livestock species, sometimes ignore the guidance of the herders and make their own way to their preferred browsing grounds. Herders have only limited control over the movements of their camels. Unlike other livestock species, camels may stall and refuse to cooperate with the herder. There are times when camels disregard plentiful browse and instead walk to find the sorts of browse they require. The herders suggested that the camels 'monitored their own physiological needs' and sought salty plants when they feel a need for salt. They might travel considerable distances to reach landscapes where such plants were found. At other times, the camels required 'dust baths', which were found in the raasa landscapes. Sometimes, the herders tried to prevent camels from browsing in landscapes with plant species that might upset the camels' digestive systems. Camels might also show signs of thirst while the forage is still green. Herders would prevent them from drinking water, realising that this would have a detrimental effect on their health. 
The Afar camel herders have developed an extensive knowledge of camel requirements and preferences, based on the soil types that are suitable for camel encampments and grazing. In the words of a key informant, 'camels and herders communicate with each other.... The camels might not talk but their behaviour is sufficient to influence herder decisions'. Occasionally, however, camels would respond unfavourably to particular soils chosen by their herders. The reason for this behaviour is not known. The herder is then forced to reassess soil conditions. According to an informant, 'A camel is a better judge of soils than the herder'. Therefore, changes in camel behaviour are good indicators of changing soil conditions. Some soils are cold at night while others are warm, and camels prefer warm soil conditions. When soil conditions do not suit them, camels become restless and shift in their crouching positions. Conversely, when the soil does suit them, they take up their crouching positions on arrival, chewing the curd. The herders use this behaviour to decide when and where to relocate the camp.

Herders also use general camel body condition as an indicator. If the grazing is suitable, this can be inferred from changes in the camels' body hair. They monitor milk yield and the rutting of the bulls. Another indicator is the condition of the rumen. Shrinking rumen in the morning and a partially full rumen in the evening (when the camels return home) suggest that the condition of the range is deteriorating. This indigenous knowledge about camels is part of a camel folklore (gaala silale baaro) that describes grazing, breeding and calving. The verses in the folklore (not presented for lack of space) describe the different grazing landscapes visited by camels and their stubbornness; at the same time, however, 'they continue to provide nourishment for human survival'. The folklore reflects the symbolic relations between herders and their camels.

\section{Evaluation of indigenous rangeland assessments by the Afar}

The survey was conducted from the town of Awash to the town of Gawane, a distance of about $170 \mathrm{~km}$ (Figure 2). The scouts have their own names for grazing landscapes (see Table 3). The Afar iddo scouts who worked on the road transects with the author provided place names such as 'Diktaa Boora', referring to a settlement named after a traditional dance. Other names were Daiiddo-Rassa (throwing stones); here, there was gray-black soil or Daamo, which refers to land overlooking a pool of water. The Afar iddo scouts did not appear to have historical explanations for the place names. They simply stated that the names were 'historical' and that they did not know their origin (the names might have belonged to groups that lived in the area before the arrival of the Afar during historical times). They nevertheless had a sound knowledge of rangeland degradation. They referred to severe levels of degradation as aboroiti baaro. This refers to rangeland that has lost herbaceous cover. Other landscapes that have lost herbaceous cover and been invaded by Prosopis species were also referred to as aboroiti baaro. If dry litter and standing grass hay were present, the rangeland was classified as kafiin isoole baaro. Degraded rangelands had lost key forage species and therefore were of little use for livestock grazing. Conversely, highly productive landscapes were called andarhaarra (Table 3).

The grazing suitability of most landscapes had deteriorated. Herder ratings were low, with the exception of one landscape that was rated as 'excellent'. This landscape formed part of a buffer zone between the Afar and the Isse Somali, and because of the 
risk of raids, it was avoided by both groups. Despite the low ratings, the landscape grazing potential was considered high. One might infer from this that the grazing landscapes had the potential to regenerate. The landscapes invaded by Prosopis species lacked a herbaceous layer under the tree canopy and this rendered them worthless for the purpose of livestock grazing (see Figure 3). Both the river floodplain and the surrounding rangelands in the Amibara and Gawane districts have impenetrable stands of Prosopis with an estimated cover varied from 60 to $100 \%$.

\section{The Afar indigenous institutions for decision-making}

At the clan level, there are customary leaders called makabantu (makaban pl.) involved in decision making in matters related to clan grazing lands, relationships with other clans, with neighbours and with the state. The fiimat abba (acting in clan policing) enforce decisions (chaara) made by the makabantu of individual clans. The clan leaders from the associated grazing (ulooto) would, as part of their strategy for coping with drought, set aside grazing lands for periods of scarcity. This system of preserving grazing for drought years is called digdeeso. The preservation comes about through consensual agreements rather than through actual policing and lasts until the grazing is opened to the communities. The system is applied to the sections of the communal grazing lands, which are most suitable for grazing. As the drought stress becomes severe and the grazing declines elsewhere, the clan elders meet whenever necessary to evaluate the situation and decide when to allow access to the preserved grazing areas (Davies and Bennet 2007).

A further option is to seek grazing in neighbouring territories. There is a tradition of mutual sharing with neighbours such as the Karayu Oromo. Clan leaders (makaban) conduct the negotiation. Communication is by word of mouth (daago) regarding such matters as rainfall distribution, the condition of pasture, and the status of livestock, human diseases and the possibility of armed conflict. The daago system facilitates communication between the makaban elder councils of different clans. Similar to the Orma and the Afar case studies, we evaluate the indigenous knowledge of the Karamojong. We present general knowledge and practices and discuss the results of the survey presented in Table 4.

\section{Case 3: Karamojong of Uganda}

Among Matheniko pastoralists, seasonal livestock grazing across the different landscapes also relies on assessments made by the traditional range scouts (ngikerebo). The wet season assessments are likely to cover large geographical areas because of the wide distribution of grazing and water sources. Assessments made during the dry season are more limited to the marshes and mountain pastures. The dry season pastures have a high grazing potential and are able to support high livestock stocking densities. Being cattle people, the Matheniko place more emphasis on cattle management than on the management of small ruminants. The status of pasture is assessed in terms of plant growth, and takes into account early regeneration (eparat echalichal) after initial rainfall showers, the maturing and flowering stages of grasses (kelebat) and the standing dry hay (athakan). The scouts determine the existing livestock density, based on the number of kraals in relation to the available grazing and water sources.

The ngikerebo scouts classified landscapes according to soil and vegetation indicators. The major landscape categories are arro (black cotton soils) and the eketela (sandy 
loam soils). Other landscapes are asinyonoit (sandy soil). The eketela landscapes have sandy soils with a high diversity of woody species. Another dominant landscape type is angromit. This type of landscape is characterised by pebbles and small stones spread on the ground surface, often mixed with soils of various colours. Taking soil type and vegetation indicators into account, the ngikerebo scouts categorize the landscapes according to their suitability for seasonal livestock grazing. The ngikerebo scouts also assessed landscapes for their suitability for mobile pastoral camps. When establishing livestock camps, soil types are the key indicators. Asinyonoit (sandy soils) is preferred for cattle camps (this is inferred from the livestock production performances). Herders assessed cattle behaviour in the morning after overnight kraaling. If the landscape is suitable, the cattle tend to sleep for longer periods, while the immature cattle are playful. The males are active in mating, and the milk yields of cows increase. The animal hair is more polished and they gain weight. Each night when the herds return home from grazing, herders pay attention to the fullness of the rumen as a sign of favourable foraging. In the morning, the rumen would still show evidence of the previous day's feeding. Herders also paid attention to cattle behaviour in their encampments. If the site is unsuitable at night, the cattle would remain standing, and they would be restless, moving about in the kraal. If the areas selected for camps were not suitable, the productive and reproductive indicators would show deterioration.

The Matheniko elders informed the author that while livestock grazing and management focuses on vegetation, the soil (ngalup) plays a crucial role in determining suitability for cattle. Soil conditions vary according to locality. The herders recognise that for the same landscape, there are 'hot' and 'cold' patches of soil at night. The warm patches 'breathed out hot air' at night. They consider such landscapes unsuitable for night kraaling. They believe that the sites that 'breathed out hot air' were associated with livestock and human diseases. The link between hot air at night and disease remains unclear, ${ }^{\mathrm{g}}$ but one may make some conjectures. What the herders referred to as 'breathing out hot air' might be a result of soils that store heat during the daytime. At night, as the air cools and the warm air rises, it might seem as if the soil was 'breathing out hot air'. The stored heat dissipates through convectional air currents, giving the impression that the land was 'breathing'. In other sites, the herders claimed that the warmth alternated with cooler conditions. They considered such soils suitable for night kraaling. The observations of the Matheniko differed from those of the Orma and the Afar, who regarded cold soil as undesirable for night kraaling, and preferred warm soils. The difference might depend on how precise their observations were.

Some landscapes are only grazed for brief periods, and have patchy vegetation. Conversely, landscapes with high grazing potential are heavily stocked. For example, the Matheniko recognized that the eketela (sandy landscapes) are more vulnerable to heavy grazing than the arro (black soils) landscapes. The latter are better able to resist heavy livestock grazing and recover rapidly. These black soil (arro) landscapes are grazed during the dry season or in a drought year, while eketela is mostly grazed during the wet season. This relationship is described in cattle folk song. The folklorist narrates how he 'listens to the demands of his bull' during a year of plenty and a year of drought.

You [i.e. the bull] graze in arro and travel to eketela ${ }^{h}$ to sleep... [in the wet season]...The drought has come and you want to migrate to Gritome... [a dry season 
refuge]. Because of hunger, you have lost weight [and], I listen to your 'crying' (bellowing), calling the name of the kraal leader to take you to Gritome....

The narration shows how a herder 'listens to and observes' his stock to make appropriate decisions. The herder expresses his concern for his herd's needs by moving them to eketela during the wet season and arro during the dry season. The drought year is a different matter. The animals' condition deteriorates because of grazing shortages and the cattle (symbolized by the bull) lose body condition. In the song, the herder expresses 'the wishes of his bull' by asking the kraal leader to take the cattle to the drought refuge in Karamojong.

\section{Evaluation of indigenous rangeland assessments of the Matheniko}

The survey was conducted for up to a distance of $80 \mathrm{~km}$ from Moroto town, first to the Kenyan border, and then along the Moroto-Kampala road (Figure 2). The ngikerebo scouts were able to explain the origin of the geographical names of the landscapes (Table 4 see endnotes). The landscapes were classified according to surface soil features (such as colour) and topographical location. Permutations of soil names are reflected in their system of classification. For example, angromit is a general classification given to landscapes that have pebbles and small stones on the soil surface. Particular landscapes are classified according to other features, such as soil colour. Examples are angromit nagor (dark soil with pebbles), angromit narangan (red soil with pebbles) or, in relation to topographical locations, angromit nalokob emoru (i.e. sloping from the mountain). For each landscape surveyed, the ngikerebo scouts determined the grazing seasons of different livestock species according to the type of vegetation.

The landscapes of the Matheniko rangelands were allocated to different season of grazing (such as wet season, dry season and drought year). In general, the grazing suitability was high for cattle and potentially high for camels but moderate for the goats. This variation was also reflected in landscape grazing potential (LGP) (see Table 4). The Matheniko's rating of grazing varied from 'poor' to 'excellent'. In their understanding of landscape changes, overgrazing alters the distribution of plant species, while landscapes that have not changed are regarded as stable. The Matheniko described gradients of grazing pressure, from heavy (adedeu), to moderate (erekeny) to ungrazed (adakar amoore) (Table 4).

The scouts' ratings were high for most of the landscapes. Furthermore, in contrast to the two other case studies, there was no evidence of invasive species in the Matheniko rangelands. For the surveyed landscapes, both the scouts and ecologist's ratings varied from fair to excellent. About $40 \%$ of the landscapes showed fair conditions, while $60 \%$ were judged to be 'good' or 'excellent'. The trends for most of the landscapes were stable. The landscapes that showed a negative trend were those situated near the security settlements. Grazing varied from heavy (near settlements) to none (in the most distant grazing landscapes). However, none of the landscapes showed any evidence of adedeu (i.e. degraded). Rather, the status of the rangelands was judged to be somewhere between erekeny (moderately used) and amoone (little used). The joint survey concludes that the Karamjong rangelands were in far better conditions than those of the two other cases. 


\section{The Matheniko's indigenous institutions for decision-making}

Traditionally, decisions were vested with the elders of the senior age set (kathiko). The senior elders would meet and discuss the migration of livestock or the protection of the community from raids or from the stresses induced by droughts. These decisions would also be discussed with the elder councils of neighbouring settlements. The 'tree of men' that comprised elder councils of the settlement and their neighbours who often meet under trees are responsible for making decisions. The elders in attendance would extensively discuss all issues relating to forage and the need for livestock migration. If the issues were forage scarcity, the elders would send the most experienced ngikerebo scouts to survey the grazing before moving any livestock. The ngikerebo scouts would evaluate both the quality and quantity of the available forage to determine the capacity of the land to support livestock. The scouts would estimate the stocking density at the sites and determine how long the grazing and water would last. The ngikerebo scouts would report to the elders. The elders would then evaluate all the information and take appropriate action. In the Karamojong society, promoting local community participations in government environmental policies is impossible if the elders are excluded from the discussions.

\section{Conclusions}

In African rangelands where scientific research is often patchy or non-existent, the pastoral communities have continued to rely on their systems of indigenous knowledge of rangeland management to make decisions that influence their livelihoods (Leach et al. 1999; Kyagaba 2004; Mapinduzi et al. 2003; Palmer and Wadley 2007; Angassa and Oba 2008; Roba and Oba 2009). In this study, we have used a research framework to understand how this knowledge functions using three case study communities. The findings showed that the three pastoral communities had an integrated social-environmental system, where herders read, assessed and interpreted the conditions of grazing landscapes. Local rangelands and their individual landscapes have identities; each has its own name and history. The landscape history describes past interactions between humans and livestock and the environment. The condition of grazing landscapes and their use by livestock has changed over time. Herders are able to grade different rangelands, from most preferred to least preferred, depending on their conditions in response to livestock uses. Soils and vegetation are fundamental to indigenous rangeland classification and assessment. Some landscapes are suited to wet-season grazing, while others are suited to dry-season grazing. In a few cases, the particular landscape could be grazed during both the wet and the dry seasons.

These knowledge systems were necessary for regulating livestock grazing patterns. All the three pastoral communities developed systems of grazing according to criteria of rangeland grazing suitability that vary for the different livestock species. Based upon experience, the herders recognize that some landscapes are more suited for grazing camels than cattle or small ruminants and that such suitability depends on the availability of key forage species. Thus, a particular landscape might have high suitability for browsing species (during a given season) but low suitability for the grazing species. While landscape grazing suitability tended to vary in space and time as well as on a scale of suitability, other criteria also existed. These criteria were used to determine the potential of different landscapes to support different livestock species. However, 
unlike grazing suitability, which varies over time, landscape-grazing potential is a permanent feature. The herder scouts were also able to determine the causes of environmental changes, and to relate this to soils and vegetation cover. The herders could describe different types of degradation gradients by pointing out areas that are at greater risk of degradation. This type of knowledge is crucial for building a baseline of information on the communal rangelands, which ecologists and policy makers would in future draw on to improve cooperation with herders.

\section{Policy implications}

At the community level, the herders' assessments were used to regulate the daily and seasonal grazing of livestock. The existence of local institutions coupled with robust indigenous methods and knowledge of environmental monitoring system suggests that governments should give serious attention to harnessing indigenous knowledge for community-level assessments to monitor the rangelands and for rapid decision-making. In this study, we did not investigate how policy makers communicate with the herders and vice versa. However, this is an important aspect of research, which needs more attention in the future. The present practice is for the Kenyan, Ethiopian and Ugandan government agencies to organize workshops (but rarely related to grazing systems) and inform the public in general about government policies on the environment, but without demonstrating how the indigenous pastoralist institutions might be targeted for information transfer. In the future, the governments could benefit by supporting indigenous rangeland management knowledge, which would require acknolwledgement of indigenous institutions, and by including these communities in land use planning. Most importantly, governments should support indigenous rangeland management knowledge by integrating it into systems of resource management, and by enlisting local communities as active participants in environmental monitoring. Promotion of local institutions is critical for achieving these goals.

\section{Endnotes}

${ }^{a}$ An informant suggested that four generations of his fathers were buried in the same site. The settlement had developed into independent settlements. ${ }^{\mathrm{b}}$ The four dedha included Korra-Bura, Galole-Hola and Waldena and the river delta (chaafa). The term chaafa also applies to the river floodplain pastures. ${ }^{\mathrm{c}}$ The kooticha soils which are vertisols become muddy when wet during the wet season and cracking dry during the dry season. ${ }^{\mathrm{d}}$ The Borana Oromo would use the term 'Komoora' when referring to the place where herds of horses were kraaled. Their hooves would tend to dig and create a depression in the ground. ${ }^{\mathrm{e}}$ The oomaar-saala landscapes tend to become dusty if trumpled upon by livestock. ${ }^{\mathrm{f}}$ After the Orma were Islamized from 1930s they abandoned the Oromo gada system and built a parallel system of the Jaarsa mata dedha. ${ }^{\mathrm{g}}$ It is common knowledge that desert temperatures will be high during the daytime, but much cooler at night. The explanation in relation to solar energy is well documented. The observations of the herders may be explained by applying the same principles. ${ }^{\mathrm{h}}$ These are key grazing landscapes. 
the project. Dr Jonathan Davies and Mr Halakhe Dida made useful comments on an earlier version of the article. Edith Mbigi and Hershil Shah are thanked for their field support. Jibril Osman assisted in the fieldwork and Hon. Ali Wario coordinated with the Orma herders. The Afar Pastoral Forum through Ismail Ali Gardo supported the fieldwork in Afar. I also thank my assistants, Sheikhu Mohamadu Said and Mahad Aman, for assisting in the surveys, and Hiriae Ali for his advice on field sites and supplying the photograph of Prosopis species used in this article. The Karamoja Agropastoral Development through Mr Simon Nangiro supported the field study in Uganda. Paul Aleper and selected elders assisted in the fieldwork in the Matheniko site. Comments by two anonymous referees and the editor improved the manuscript.

\section{Competing interests}

The author has no competing interests.

Received: 2 September 2011 Accepted: 27 March 2012 Published: 27 March 2012

\section{References}

Agade, KM. 2010. Complexities of livestock raiding in Karamoja. Nomadic Peoples 14: 87-105.

Angassa, A, and G Oba. 2007. Relating long-term rainfall variability to cattle population dynamics in communal rangelands and a government ranch in southern Ethiopia. Agricultural Systems 94: 715-725. doi:10.1016/j.agsy.2007.02.012.

Angassa, A, and G Oba. 2008. Herder perceptions on impact of range enclosures, crop farming, fire ban and bush encroachment on the rangelands of Borana, southern Ethiopia. Human Ecology 36: 201-215. doi:10.1007/s10745-0079156-z.

Berlin, B. 1973. Folk systematic in relation to biological classification and nomenclature. Annual Review of Ecology and Systematics 4: 259-279. doi:10.1146/annurev.es.04.110173.001355.

Boardman, J, J Poesen, and R Evans. 2003. Socio-economic factors in soil erosion and conservation. Environmental Science and Policy 6: 1-6. doi:10.1016/S1462-9011(02)00120-X.

Bouh, AM, and Y Mammo. 2008. Indigenous conflict management and resolution mechanisms on rangelands in Somali Regional State, Ethiopia. Nomadic Peoples 12: 109-121. doi:10.3167/np.2008.120107.

Brouwer, F, and B Crabtree. 1999. Environmental indicators and agricultural policy. Wallingford, UK: CABI Publishing.

Dale, VH, and SC Beyeler. 2001. Challenges in the development and use of ecological indicators. Ecological Indicators 1: 3-10. doi:10.1016/S1470-160X(01)00003-6.

Davies, J, and R Bennet. 2007. Livelihood adaptation to risk: Constraints and opportunities for pastoral development in Ethiopia's Afar Region. Journal of Development Studies 43: 490-511. doi:10.1080/00220380701204422.

Ensminger, J, and A Rutten. 1991. The political economy of changing property rights: Dismantling a pastoral commons. http://www.jstor.org/stable/645447. Accessed 27 January 2012.

Kebebew, Fassil, Dirres Tsegaye, and Gry Synnevåg. 2001. Traditional coping strategies of the Afar and Borana pastoralists in response to drought., DCG Report, No. 17.

Fernàndez-Gimenez, MA. 2000. The role of Mongolian nomadic pastoralists' ecological knowledge in rangeland management. Ecological Applications 5: 1318-1326.

Ford, J, and D Martinez. 2000. Traditional ecological knowledge, ecosystem science, and environmental management. Ecological Applications 10: 1249-1250. doi:10.1890/1051-0761(2000)010[1249:TEKESA]2.0.CO;2.

Getachew, KN. 2001. Among the pastoral Afar in Ethiopia: Tradition, continuity and socio-economic change. Utrecht, The Netherlands: International Books in association with OSREA.

Grice, AC, and KC Hodgkinson. 2002. Challenges for rangeland people. In Global rangelands progress and prospects, ed. Grice AC, Hodgkinson KC. 1-9. Wallingford, UK: CABI Publishers.

Griffin, G. 2002. Indigenous peoples in the rangelands. In Global rangelands: Progress and prospects, ed. Grice AC, Hodgkinson KC. 29-41. Wellingford, UK: CABI Publishing.

Illius, AW, and TG O'Connor. 2000. Resource heterogeneity and ungulate population dynamics. Oikos 89: 283-294. doi:10.1034/j.1600-0706.2000.890209.x

Kassahun, A, HA Synman, and GN Smit. 2008. Impact of rangeland degradation on the pastoral production systems, livelihoods and perceptions of the Somali pastoralists in Eastern Ethiopia. Journal of Arid Environments 72: 1265-1281. doi:10.1016/j.jaridenv.2008.01.002.

Knighton, B. 2010. 'Disarmament': The end or fullment of cattle raiding? Nomadic Peoples. 14: 123-146.

Kyagaba, E. 2004. Range resource assessment and monitoring techniques among the pastoral Bahima in Uganda. Nomadic Peoples 8: 81-97. doi:10.3167/082279404782066078.

Leach, M, R Means, and I Scoones. 1999. Environmental entitlements: Dynamics and institutions in community-based natural resource management. World Development 27: 225-247. doi:10.1016/50305-750X(98)00141-7.

Little, PD. 2003. Pastoral ecologies: Rethinking interdisciplinary paradigms and the political ecology of pastoralism in East Africa. In African savannas: Global narratives and local knowledge of environmental change, ed. Bassett TJ, Crummey D. 161-177. Oxford: James Currey.

Mapinduzi, AL, G Oba, RB Weladji, and JE Colman. 2003. Use of indigenous ecological knowledge of the Maasai pastoralists for assessing rangeland biodiversity in Tanzania. African Journal of Ecology 41: 329-336. doi:10.1111/j.13652028.2003.00479.x

Müller-Mahn, D, S Rettberg, and G Getachew. 2010. Pathways and dead ends of pastoral development among the Afar and Karayu in Ethiopia. European Journal of Development Research 22: 660-677. doi:10.1057/ejdr.2010.37.

National Academy of Sciences (NAS). 2000. Ecological indicators for the NationWashington, DC: National Academy Press.

Oba, G, E Post, PO Syvertsen, and NC Stenseth. 2000. Bush cover and range condition assessments in relation to landscape and grazing in southern Ethiopia. Landscape Ecology 15: 535-546. doi:10.1023/A:1008106625096.

Oba, G, and G Kotile. 2001. Assessments and landscape level degradation in southern Ethiopia: Pastoralists versus ecologists. Land Degradation \& Development 12: 461-475. doi:10.1002/ldr.463.

Oba, G, and LM Kaitira. 2006. Herder knowledge of landscape assessments in arid rangelands in northern Tanzania. Journal of Arid Environments 66: 168-186. doi:10.1016/j.jaridenv.2005.10.020. 
Oba, G, E Sjaastad, and HG Roba. 2008. Framework for participatory assessments and implementation of global environmental conventions at the community level. Land Degradation \& Development 19: 65-76. doi:10.1002//dr.811.

Oba, G, P Byakagaba, and A Angassa. 2008. Participatory monitoring of biodiversity in East African grazing lands. Land Degradation \& Development 19: 636-648. doi:10.1002/ldr.867.

Palmer, CT, and RL Wadley. 2007. Local environmental knowledge, talk, and scepticism: Use 'LES' to distinguish 'LEK' from 'LET' in Newfoundland. Human Ecology 35: 749-760. doi:10.1007/s10745-006-9108-z.

Reed, MS, and AJ Dougill. 2002. Participatory selection process for indicators of rangeland condition in the Kalahari. The Geographical Journal 168: 224-234. doi:10.1111/1475-4959.00050.

Rettberg, S. 2010. Contested narratives of pastoral vulnerability and risk in Ethiopia's Afar region. Pastoralism 1(2): 248-273.

Roba, HG, and G Oba. 2008. Integration of herder knowledge and ecological methods for land degradation assessment around sedentary settlements in a sub-humid zone in Northern Kenya. International Journal of Sustainable Development \& World Ecology 15: 251-264. doi:10.3843/SusDev.15.3:8.

Roba, HG, and G Oba. 2009. Community participatory landscape classification and biodiversity assessment and monitoring grazing land in northern Kenya. Journal of Environmental Management 90: 673-682. doi:10.1016/j.jenvman.2007.12.017.

Scharieka, N. 2001. Environmental knowledge and pastoral migration among the Wodaabe of south-eastern Niger. Nomadic Peoples 5: 65-88. doi:10.3167/082279401782310934.

Stites, E, and D Akabwai. 2010. 'We are now reduced to women': Impacts of forced disarmament in Karamoja, Uganda. Nomadic Peoples 14: 24-43. doi:10.3167/np.2010.140203.

Turner, MD, and P Hiernaux. 2002. The use of herders' accounts to map livestock activities across agro-pastoral landscapes in semi-arid Africa. Landscape Ecology 17: 367-385. doi:10.1023/A:1021238208019.

Unruh, JD. 2005. Changing conflict resolutions in the Ethiopian pastoral commons: The role of armed confrontations in rulemaking. GeoJournal 64: 225-237. doi:10.1007/s10708-005-5650-2.

doi:10.1186/2041-7136-2-1

Cite this article as: Oba: Harnessing pastoralists' indigenous knowledge for rangeland management: three

African case studies. Pastoralism: Research, Policy and Practice 2012 2:1.

\section{Submit your manuscript to a SpringerOpen ${ }^{\circ}$} journal and benefit from:

- Convenient online submission

Rigorous peer review

- Immediate publication on acceptance

- Open access: articles freely available online

- High visibility within the field

- Retaining the copyright to your article

Submit your next manuscript at $\gg$ springeropen.com 